\title{
A Review on Art of Creating Values in Retail for Improving Business Performance
}

\author{
Sunil Atulkar ${ }^{1} \&$ Dr. Bikrant Kesari ${ }^{2}$ \\ ${ }^{1}$ Senior Research Fellow, Department of Management Studies (MANIT Bhopal), India \\ ${ }^{2}$ Assistant Professor, Department of Management Studies (MANIT Bhopal), India \\ Correspondence: Sunil Atulkar, Senior Research Fellow, Department of Management Studies (MANIT Bhopal), \\ India
}

Received: February 13, 2018

Accepted: February 26, 2018

Online Published: March 13, 2018

doi:10.5430/jbar.v7n1p22

URL: https://doi.org/10.5430/jbar.v7n1p22

\begin{abstract}
Today the retail business environment becomes more complex and unpredictable in nature. In this research article researchers try to discus on engagement of arts in creating values in retail sector organisations. As the art based methods are used in various organisational developments, so this paper focused on four processes proposed by Darso and Dawids (2002) in retail sector organisation, to identify how these methods innovatively works on retail customers and why these process are important for the retail organisation performance. We identifies that the retailers should have to focus on the use of arts based method such as decoration, entertainment, developing the high skilled employees and attractive retail environment, enables customer to see the retail store environment more differently which helps in improving the performance of retail sector organisations. Based on the review of earlier published literatures, the present study shows that the uses of arts in creating shopping values more innovative, effectively and efficiently in retail sector organisations, have become a key to develop the effective business strategy to get competitive advantages over others.
\end{abstract}

Keywords: retail sector, retail environment, shopping values, arts in business, business strategy, organisational performance

\section{Introduction}

Creating retail environment more attractive and startling is an art to communicate the assurance of merchandise delivered and experienced by the customer during shopping process. Undoubtedly, the retail industry is a one of the fastest growing, changing and dynamic industries in the world today. Recent years have brought winds of change to the retail industry for Indian market. IBEF Report (2013) shows that India is ranked fifth in the Global Retail Development Index in 2012 because of increased urbanization, consumerism and emergence of organized retail outlets in the form of malls and hypermarkets in which hypermarkets would be the largest retail segment, accounting for $21 \%$ of total retail space by 2013-2014. Artful creation of shopping value in the retail store is an essential part of retail business strategy. Currently the organized retail sector in India constitutes $8 \%$ of the total retail market than traditional retail and it is expected to gain the share of $20 \%$ by 2020 (Deloitte, 2013). Besides selling merchandise to the customer from retail outlets, retailers are more focused toward a role of providing better services to customer. Darso and Dawids (2002), study presents four options to Arts-in-Business: "arts as decoration, art as entertainment, arts as instruments, and the arts as a strategic process" of transformation for the business activities. Behind this concern the questions of how these four options of Arts-in-Business will be effective for creating values in retail sector organisations. As there is a rising appreciation of more creative and innovative work for creation of shopping values (Babin et al., 1994; 2005) artistically. The development of personal and organisational creativity is repeatedly cited as an essential requirement for today's organisations (Amabile et al., 2005). The applications of art in creating value makes the purchase decisions easier for the customer and they can share their observed experience with their peer group members facilitate retail organisation to focus on use of arts in retail business (Atulkar and Kesari, 2014). The learning's of retail environment is necessary for the development of retail marketing strategies (Arnold and Reynolds 2003), retail store performance and also for the benefit of the staff performance in this competitive environment. In response to the research question in the recent research on retail sector, the main objective of this study is how the artful creation of values using four options of arts in business will help in improving the performance of retail sector organisation in India (Kesari and Atulkar, 2015). Based on the literature reviews of 
earlier published papers, this study tries to recognize the use of arts in value creation, helps retailer to design their store layout and environment more positive, attractive, exciting, innovative and motivated, which energies the customer to shop from particular retail stores.

\section{Literature Review}

\subsection{Arts of Creating Values}

Babin et al. (1994) study verifies the existence of shopping values in the customer, shows that the perceived satisfaction from the product will influences customer shopping behaviour. A review on shopping values (Babin et al., 1994, Wakefield and Baker, 1998; Babin et al., 2005) indicates that the shopping behaviour of the customer is influenced by perceived values at retail store. It is argued that creating customer value is an art for producing satisfaction and purchase intention for the product and services in the customers (Atulkar and Kesari, 2017) and most of the time the retail business organisation spend lot of time on preparing the artistic ways to improve retail business performance. Every customer loves the exclusivity of knowing the new and exciting thinks related to product, which retailers have to focus, makes consumers to feel like insiders. They are placing importance on intrinsic values such as kindness and collaboration at the retail store while making purchase. Study of Darso (2013), a distinguished researcher, describes the four levels of arts in business, which we have used for creating values of retail sector organisation for the organized retail customer.

\subsubsection{Arts as Decoration}

Retail store environment should be more decorative and attractive which can remove the strain and negative emotions from customer mind and create emotional connectivity of customer with retail store and sales staff. Therefore, the organized retail store owners invest more on store designing by using bright colours, proper colourful lightings, promotional pamphlet, and physical facilities for providing shopping convenience (Chandon et al., 2000). Bloch et al. (1994) showed that hedonic shoppers experience higher pleasure and arousal from the use of art as decoration from shopping process. To keep the products in the public eye, the retailer have to demonstrate products artistically encourage customers to connect with the merchandise at their sensual level. The art of shifting customer preferences of everyday products was investigated by Hagtvedt and Patrick (2006) and this art infusion theory not only influences evaluations, but also has a capacity to reduce emotional responses (Darso, 2013). It has been observed that during festive season retailer sales their products with decorative packaging or in decorated shopping bags, reused by the customer as gift bags or as shopping bags. Sometimes the packaging is so important that is used over and over for other products that do not relate to the packages. Hence, the decorative packaging of the product has become more desirable as a symbol, which feels customer enchantment, ultimately leads to make more purchase (Atulkar and Kesari, 2014). Artistic use of colour combination in the retail store instantly impact on customer's moods and emotions towards retail store. For example when displaying any dark colour dresses, retailer may put them on in front of a bright colour wall to stimulate the magnetism in the customer.

\subsubsection{Arts as Entertainment}

Organized retail stores are viewed as a place for entertainment (Bloch et al., 1994), where the customer does not purchase products or items purely based on usability in order to satisfy their need recognition. Today the shopping in this modern era clubbed with entertainment facilities, which consumers look for during their shopping trip. Thus, the artful use of entertainment facilities like soft music and aromatic environment, artistic paintings on the walls, refreshment facilities and gaming zone for the children's generate pleasure and enjoyment (Arnold and Reynolds, 2003) in the customer. Therefore, the retailers that want to compete efficiently in this customer era must be able to appeal the customers need and demand more than the offered products and services. Retailers have to induce art in marketing activities to differentiate itself from other through entertainment activities and reduce the visual confusion of the modern world by activating customer's emotions through entertainment. Study of Sinha and Banerjee (2004) observes that the shoppers in the category of leisure stores place a greater importance to the values provided by entertainment. Therefore, the artistically use of bright colours, aroma and sitting areas design in the organized retail stores encourage customers to relax and refresh their mood (Wakefield and Baker, 1998). Some time the retailers invite television artists for the promotion of product launch, movies and promotional events on special occasions at organized retail store creates excitement in the customer (Babin et al., 1994).

\subsubsection{Arts as Instrument}

Arts is used as an instrument for the development of sales staff such as skill development, works in a team and motivation through appreciation in order to improve the employee performance collaborates with organisational performance. Darso and Dawids (2002) initially identify behaviours and competencies that reflect improved 
performance benefits from arts-based learning. According to Schmitt and Simonson (1997), the customers always looking beyond the basic functions of a product of services, when making any purchase decision related to product or services. Thus, the use of arts in the retail stores and its performance in the market plays an important role in preparing retail business strategies. Use of arts in teambuilding, communication training, leadership development, problem solving and innovation processes (Darso, 2013), motivate employees to work effectively and efficiently for improving organisational performance. Self-expression of the customer is the instrument via social media, blogging and email marketing to capturing the view point of the customer related to the product or retail store.

\subsubsection{Arts as Strategy}

Strategy shows the direction and scope to the organisations over the long-term, helps in achieving the advantages in a changing environment with the aim of fulfilling customer's expectations. While preparing the business strategy arts work a lot. Before preparing any new business strategy for the retail store businesses, retailer have to focus on pitfall and how effective they are in the start-up in the earlier, then spotlight on current strategy. It enlarges the thinking, the openness of ideas, willingness to expand into more and different things (Darso and Dawids, 2002). To get success in this competitive retail environment it is important to see the future differently (Antal and Strauß, 2013) and the ability to see differently the futuristic new horizons of business that will boost business in the near future is an art. It is also important for the retailers to understanding the customer shopping experience (Atulkar and Kesari, 2016) with patronage behavioural responses for better management of strategies in the retail stores, enhances the retail store performance.

\subsubsection{Arts of Appealing the Sense}

The purpose of use of artistic qualities to various aspects of retail store environment by using above discussed four processes is essential to draw attention and creating interest when the customers are not actively seeking information about the products (Crader and Zaichkowsky, 2001). Vision is the main component of any retail organisation, because the visual aspect of merchandise is what a customer first connects when shopping (Babin et al., 1994). This sensory stimulation creates an image, impressions, and emotional attachment or association with the product which determines whether the product will be acquired by the potential buyers or not. While shopping customer interact with same product offered by multiple brands, compelling marketers to use colour, contrast, context and packaging arts to shift customer preference (Atulkar and Kesari, 2014) to achieve success in today's market.

It is a behavioural response to move closer to the merchandise, touching the product for observing the appearance, design and quality before purchasing (Bloch et al., 2003). This can happen not only with the luxuries product (Crader and Zaichkowsky, 2001) but even for the food items also. While purchasing cloths customer first take the trial, fit to them comfortable them after the customer will take the purchase decision. Maximum time in FMCG retail outlets it has been observed that stimulation created by touching the products creates an excitement, emotional connection with the product and produces pleasure of shopping process, force customer to make impulse purchases (Atulkar and Kesari, 2017). Use of music in the retail stores environment unknowingly change the behaviour of customers and generate excitement and enjoyment (Wakefield and Baker, 1998; Arnold and Reynolds, 2003) of shopping process. Familiarities of the music will affect the perception of the customer to react positively and negatively when the music is not comfortable to them. So, the customer spends more time in the musical retail store environment. Aroma or odours produced in the retail store can stir emotions, create calming feeling and relieve from stress (Crader and Zaichkowsky, 2001), and also creates a connection between a particular scent with the brand or products. When the customer smells the same aroma in any other place or time, they will memorize the experience and emotions tied with retail store either it may be in the form of good or bad feelings. The fragrance processed can be either ambient or non ambient. Taste preferences are also related to culture motivate retailer to make use of art through in-store sampling according to the taste of different culture and societal peoples (Atulkar and Kesari, 2016).

\section{Discussion}

To compete today's competitive challenging retail environment the retailers have to work harder continuously to build a watertight business activities artistically. Today the retail business environment becomes more complex and images, arts and performances have become a key part to develop the effective business strategy (Darso, 2013). It is crucial to address the many possibilities that arts have to offer, not only as a key for success, but as a way of empowering and opening new horizons in life and business to understanding and seeing the visible world (Darso, 2013). So, the retailers should have to invest their time and energy for using of arts in developing the high skilled employees, which enables customer to see the retail store environment more differently (Antal and Strauß, 2013). Having all the discussed four processes arts as decoration, arts as entertainment, arts as instrument and arts as 
strategy proposed by Darso (2013) present in retail business with artistic linkages is responsible for shift the customer senses positively.

Discussion on appealing the senses it is observes that the infusion of arts in visualization (Crader and Zaichkowsky, 2001) not only influences comprehension and valuation of unrelated product competently but also it creates awareness, customer loyalty and relationship about the merchandise to be purchased. So, the retailer will focus on pricing, packaging, brandings, promotion, layout design (Schmitt and Simonson, 1997) that focuses customer attention. Touching is a response to connect them with the product and this tendency is found highly in a retail store, which helps in increasing the sales. Parallel to this the hearing the soft music played in retail stores make customer to relax and refresh their mood from their daily routine hectic schedule. The presence of ambient scent in the retail environment increases positive response, even the scent has no connection with the product (Henderson, 1996). Finally, the taste contributes the experience of customer for perceived products (Crader and Zaichkowsky, 2001). Companies always try to develop new concoctions to satisfy the changing taste of customer. Thus, appealing the customer senses (vision, touch, hear, smell, and sometime taste) in the retail store environment, considered as a way by which the retailers encourage their costumers to connect with the merchandise offered at retail stores.

\section{Conclusion}

The study conclude that the retailer have to identified the behaviours and competencies aspects of retailing that helps in improve the performance benefits from arts-based learning, benefits the retail sector organisation. Thus, the retailers have to sell the philosophy related to the product rather than selling the product to the customer to inspire brand advocates in the form of lifestyle. By developing one to one relationships with the customer and writing email related to how they feel in the retail environment, retailers can easily solve the problems and build connections with them. Today the customers are differs from each other in the retail store environment with shopping values. Therefore, the understanding and knowledge about the customer shopping values helps retailers to design their store environment artistically to motivate and satisfy the particular needs of customer. Finally, the customers who buy products or services from the particular retail store aren't just customers; they can be the best ambassadors of product passing through the use of arts in retailing. Thus, use of art in retail store helps retailer in generating positive evaluation and comforts to shop by providing excellent customer services and loyalty programmes.

\section{References}

Amabile, T.M., Barsade, S.G., Mueller, J.S. \& Staw, B.M. (2005). Affect and creativity at work. Administrative Science Quarterly, 50, 367-403. https://doi.org/10.2189/asqu.2005.50.3.367

Antal, A.B. \& Strauß, A. (2013). Arts in management. International Journal of Professional Management, Special Edition, 8(5), 17-28.

Arnold. M.J. \& Reynolds, K.E. (2003). Hedonic shopping motivations. Journal Retail, 79(1), 77-95. https://doi.org/10.1016/S0022-4359(03)00007-1

Atulkar, S. \& Kesari, B. (2014). A Review of customer preference towards organized retail stores. IRC's International Journal of Multidisciplinary Research in Social \& Management Science, 2(3), 24-28.

Atulkar, S. \& Kesari, B. (2014). Adoption of retailer centric philosophy in organizing buying process: A case study on Indian buying systems. ZENITH International Journal of Multidisciplinary Research, 4(9), 204-209.

Atulkar, S. \& Kesari, B. (2016). Shopping experience of hypermarket shoppers in weekends. Indian Journal of Marketing, 11, 36-49. https://doi.org/10.17010/ijom/2016/v46/i11/104738

Atulkar, S. \& Kesari, B. (2017). Impulse buying: A consumer trait prospective in context of central India. Global Business review, 19(2), 1-17.

Atulkar, S. \& Kesari, B. (2017). Satisfaction, loyalty and repatronage intentions: Role of hedonic shopping values. Journal of Retailing and Consumer Services, 39, 23-34. https://doi.org/10.1016/j.jretconser.2017.06.013

Babin, B.J., Darden, W.R. \& Griffin, M. (1994). Work and/or fun: Measuring hedonic and utilitarian shopping value. Journal of Consumer Research, 20(4), 644-656. https://doi.org/10.1086/209376

Babin, B.J., Lee, Y.K., Kim, E.J. \& Griffin, M. (2005). Modeling consumer satisfaction and word-of mouth: restaurant patronage in Korea. Journal of Service Marketing, 19(3), 133-139. https://doi.org/10.1108/08876040510596803

Bloch, P.H., Ridgway, N.M. \& Dawson, S.A. (1994). The shopping mall as consumer habitat. Journal of Retailing, 70(1), 23-42. https://doi.org/10.1016/0022-4359(94)90026-4 
Chandon, P., Wansibk, B. \& Laurent, G. (2000). A benefit congruency framework of sales promotion effectiveness. Journal of Marketing, 64(4), 65-81. https://doi.org/10.1509/jmkg.64.4.65.18071

Crader, S. \& Zaichkowsky, J.L. (2001). The Art of Marketing. Brick and Mortar Shopping in the 21st Century. Tina M. Lowrey, Editor, Erlbaum publishers.

Darso, L. \& Dawids, M. (2002). Arts-in-Business-Proposing a theoretical framework. Presented at EURAM Stockholm, May 2002, at the 5th Art and Business Conference, Borl, Slovenia, June 2002, and at The Art of management and Organisation, London, Sept. 2002.

Darso, L. (2013). Artful creation: Learning-tales of arts-in-business. International Journal of Professional Management, 8(5), 08-16

Deloitte report. (2013). Indian retail market opening more doors 2013. Retrieved from http://rasci.in/downloads/ 2013/Indian_Retail_Market_Opening.pdf

Hagtvedt. H. \& Patrick, V.M. (2006). Art infusion: How the presence of art affects the perception and evaluation of non-art products. In proceedings of the American Association of Marketing Educators meeting.

Indian Brand Equity Foundation (IBEF) report. (2013). Retail. Retrieved from http://www.ibef.org/download/ Retail-March-220313.pdf

Kesari, B. \& Atulkar, S. (2015). A review on retailing prospects of Indian rural market: Issue and challenges. MERC Global International Journal of Social Science and Management, 2(3), 193-210.

Schmitt, B. \& Simonson, A. (1997). Marketing aesthetics: The strategic management of brands, identity, and image. New York: The Free Press.

Sinha, P.K. \& Banerjee, A. (2004). Store choice behaviour in an evolving market. Journal of Retailing and Distribution Management, 32(10), 482-494. https://doi.org/10.1108/09590550410558626

Wakefield, K.L. \& Baker, J. (1998). Excitement at the mall: determinants and effects on shopping response. Journal of Retailing, 74(4), 515-539. https://doi.org/10.1016/S0022-4359(99)80106-7

Westbrook, R.A. \& Black, W.C. (1985). A motivation-based shopper typology. Journal of Retailing, 61(1), 78-103. 